\title{
COMMENT
}

\section{THE INVESTMENT COMPANY ACT IN THE STATE COURTS}

The Investment Company Acr $^{1}$ [ICA] confers concurrent juris-
diction upon state and federal courts to enforce its provisions. ${ }^{2}$ During twenty-one years of exclusively federal attention, ${ }^{3}$ some federal courts have recognized private rights of action in addition to the regulatory provisions of the act. Two recent decisions of the Delaware Court of Chancery are the advance guard of a large number of cases in which plaintiffs are asserting such private rights of action in state courts. ${ }^{5}$ In Lutz v. Boas ${ }^{\mathbf{B}}$ and Saminsky v. Abbott, ${ }^{7}$ the Delaware court granted relief alternatively under its own common law, or the ICA, as that act has been construed by some federal courts.

Two decades of federal litigation have left unsettled the exact theory by which these private rights of action are granted under the ICA. 8 Thus state courts soon will face not only the problems of con-

\footnotetext{
I 54 Stat. 789 (1940), as amended, 15 U.S.C. § $80 a$ (1958).

54 Stat. 844 (1940), 15 U.S.C. $\$ 80 a-43$ (1958). See note 20 infra for text of this section.

'This statement is based on a search of the fifty state Shepard's Citators from the date of passage of the ICA through the advance sheets current in late 196r. The dearth of state court cases apparently reflects both the previous lack of interest in the act, and a desire on the part of plaintiffs to take advantage of more favorable precedents in the federal courts.

-The ICA primarily consists of regulatory provisions, the only exception being $\S 30(f)$. See note 34 infra.

'Approximately sixty derivative suits were pending in early $196 \mathrm{x}$. May, Observations, I 93 The Commercial and Financial Chronicle 968 (1961). Most of these were in the federal courts. It is particularly significant that the Delaware Court of Chancery now recognizes these causes of action, for it has long been a great maker of corporation law. Delaware is also the corporate "home" of many investment companies, making them more amenable to suit in that state.

${ }^{\circ}$ 7 1 A.2d $38 \times$ (Del. Ch.), hearing on subsequent developments, 76 A.2d 853 (Del. Ch. I961).

${ }^{7}$ CCH Fed. Sec. L. Rep. 9 91,047 (Del. Ch. Sept. 18, 1961).

3 The uncertainty is exemplified in the opposite holdings in Brouk v. Managed Funds, Inc., 286 F.2d 901 (8th Cir.), cert. granted, 366 U.S. 958, Motion of Solicitor General for leave to participate in oral argument granted, 368 U.S. 873 (x96r), where the existence of private rights of action beyond those expressly included in the statute was denied and in Brown v. Bullock, 194 F. Supp. 207 (S.D.N.Y.), aff'd, 294 F.2d
} 
current division of state and federal jurisdiction created by the ICA, but also the act's effect upon the private litigant.

\section{The Investment Company Industry}

Although investment companies were in existence before the turn of the century, they have risen to major economic importance in the United States only in the last two or three decades. In the last twenty years their total assets have multiplied nine and one-half times, and some authorities predict that an industry comparable in magnitude to insurance is now in its formative years. ${ }^{10}$

In the usual industry context, an investment company is one corner of a triangle composed of the investment company, the investment adviser, and the underwriting organization. The investment adviser furnishes securities research and analysis services to the investment company and often specific advice on when to buy and sell given securities. The working relationship of these two entities is governed by the advisory contract. ${ }^{11}$ The underwriting organization, with its sales and promotional force, undertakes to distribute investment company shares to the public. The underwriter and the dealers through whom it often operates are compensated by a fraction of the sales load, i.e., a markup over the net asset value of the shares. There are several types of investment companies, the most significant being the management com-

415 (2d Cir. 1961 ), where such rights were recognized. This conflict is discussed in Comment, 1961 DUXE L.J. 421.

- There have been two periods of growth of investment companies; one before the 1929 market decline and the present period, which began in the mid-1940's and showed its greatest strength before 1950. I Loss, SEcurities REculation 144-47 (2d ed. 1961) [hereinafter cited as Loss]; PLUM \& HUMPHREY, INVESTMENT ANaLYSIS AND MaNaGement 569-76 (1955).

${ }^{10} 26$ SEC ANN. REP. 169 (1960). One authority, Arthur Wiesenburger \& Co, predicts that the investment company industry will have assets exceeding 100 billion dollars by 1980. This figure is based on an extension into the next two decades of one-half of the growth rate of investment companies between 1955 and 1960 . In evaluating this prediction, it should be remembered that during the past five years, we have been caught up in a "bull" market, that is, a rising market, replete with investor courage. Investment coinpanies thrive on a rising market for at least two reasons: (1) investor confidence, revulting in larger sales of investment contracts, and (2) appreciation of the common stock held by the companies. Notwithstanding these mitigating cousiderations and in the abrence of a major business failure, it is fairly certain that investment companies will occupy an increasingly important role in the American economic picture in the years ahead. Arthur Wiesenberger \& Co., Inteatuent CouPANIES 9 ( 1960 ed.)

${ }^{11}$ The advisory contract is now governed by 8 I5 of the ICA, 54 Stat. 812 (1940), 15 U.S.C. $\& 80 a-15$ (1958). 
pany, ${ }^{12}$ a company controlled by a board of directors having broad, discretionary powers extending beyond those of a mere custodian or trustee.

Federal regulation, originating in the enactment of 1940, was predicated on major abuse in the industry. ${ }^{13}$ Testimony before congressional committees during hearings on the proposed ICA revealed that investment companies were often used by management for purposes which were not in the best imterests of shareholders. ${ }^{14}$ Officers and managers sometimes bought securities from controlled investment companies at a discount from the market price or sold securities to them at unfair prices. ${ }^{15}$ In at least a few of the broker-controlled companies, management was not above "churning" the portfolio."16

After investors had purchased shares in investment companies on

1326 SEC ANN. REP. 169 (1960). See also 54 Stat. 799 (1940), 15 U.S.C. \& 80a-4 (1958) (classification of investment companies); 54 Stat. 800 (1940), 15 U.S.C. \& 80a5 (1958) (subclassification of management companies).

"2f. SEC, Report on Investment Trusts and Investment Companies pt. II, at 504, 505 (1939) (Table 155 and Chart 48).

16 "The outstanding features of the management policies of many investment companies reveal a consistent relationship to the private business interests of the sponsor. Investment companies sponsored by brokers frequently show active trading in portfolio securities; companies sponsored by investment bankers show portfolios heavily weighted with security issues underwritten by the sponsors and a large proportion of underwritings shared with sponsors; companies sponsored by industrial promoters show portfolios favoring large blocks of securities-available as instrumentalities of controlin various industrial enterprises in which the sponsors were interested." SEC, REPORT ON INVESTMENT TRUSTS AND INVESTMENT COMPANIES pt. III, at 2486-87 (1941).

${ }^{15}$ See SEC, Report on Investment Trusts and Investment Companies pt. III, at 22 (1940) and pt. III, at 2635 (1941).

16 "Churning" denotes the rapid buying and selling of securities to generate additional brokerage fees rather than to gain an advantage in the market for the investor. This abuse was often found in broker-controlled companies. Lutz v. Boas, i 7 I A.2d $38 x$ (Del. Ch. 196r), illustrates another context in which "churning" may be found. The sale of investment contracts is facilitated by an attractive earnings record. Investment company earnings are produced in large measure by realized capital gains. Thus the choice between selling for an immediate declarable gain and holding for a more prudent (in the terms of long range gain) selling opportunity can be influenced by the desire of the underwriter to "declare dividends." In the Lutz case, the Slayton brothers, dominating the investment company, the investment company adviser and the underwriter, harnessed the policies of the investment company to the needs of the underwriter and "churning" resulted.

Besides the additional profits for the underwriter, there was another reason for the "churning" license extended to the broker in the Lutz case, namely the kickbacks from the broker to the investment adviser. These kickbacks took the form of free invertment advice and hiring the Slayton's relatives for "paper jobs" in Miami Beach. Eventually the broker assumed the function of the investment adviser, leaving it with a sizeable fee from the investment company - but no work load. 
the basis of the reputation and standing of the then-existing investment adviser, the investment advisory contract or control of the investment adviser was sometimes purchased by a group which had different policies or which was incompetent or dishonest. Control of the investment company itself was occasionally "sold" to unreliable persons who looted the highly liquid corporate assets. ${ }^{17}$

Boards of directors of some management companies took advantage of their broad power and altered the basic investment policy of their companies, to the serious prejudice of non-consenting shareholders. ${ }^{18}$ Often the board of directors retained its power through inequitable stock structures and by pyramiding one investment coinpany on another. ${ }^{10}$

It is against this background of abuse that private rights of action, similar to those which first found expression in the federal courts, are being brought in the state courts. As these actions are brought, it will be necessary for state courts to inquire into their duty to accept jurisdiction and into the theories by which these rights are established.

\section{The Duty of State Courts to Enforce the ICA}

State and federal courts have concurrent jurisdiction to enforce

${ }^{17}$ Even during the period of the great market decline, when investment securities were selling at discounts from their asset value, "many individuals . . ., alert to the possibilities of profit from the control of such funds, were willing to pay sums substantially in excess of asset and market values to existing controlling interest for their holdings in companies to be acquired." SEC, REPORT ON INVESTMENT TRUSTS AND INVESTMENT COMPANIES pt. III, at 23 \& n.I85 ( 1940 ).

For an analysis of sale-of-control problems, especially in investment companies, see generally Comment, Sales of Corporate Control at a Premium, 196 I DUKE L.J. 554.

A distinction has recently been drawn between the sale of "control" and the sale of a controlling block of securities of the investment company. See Willheim v. Murchison, 30 U.S.L. WEEK 2483 (S.D.N.Y. March 29, I962); cf., SEC v. Insurance Sec, Inc., 254 F.2d 642 (9th Cir.), cert. denied, 358 U.S. 823 (1958), affirming, 146 F. Supp. 778 (N.D. Cal. 1956).

${ }^{10}$ The investment policy of an investment company is important to the shareholder, because, in the typical case, he is looking for a particular type of risk. Some investore prefer high risk securities with growth potential while others prefer more stable investments. Since the investment company shareholder ordinarily incurs a "gales load" of some eight per cent when he buys his shares, ArTHur Wiesengerger \& Co., op. cit. supra note 10, at 234 , he cannot, without substantial penalty, protect himself by trading out of a company whose policy has changed. Therefore it is in the interest of investors for these companies to announce and adhere to a fixed policy. This problem is now covered by $\S 13$ of the ICA. 54 Stat. 811 (1940), I5 U.S.C. $\$ 80 a-13$ (1958).

10 These problems are treated in 54 Stat. 817 (1940), is U.S.C. $8802-18$ (1958) (prohibitions against inequitable capital structure), 54 Stat. 826 (1940), Is U.S.C. \& 80a-25 (1958) (reorganization plans). 
rights and duties arising under the Investment Company Act. ${ }^{20}$ Upon its face, the section of the ICA which bestows this jurisdiction upon the state courts is permissive rather than obligatory. In this respect it closely parallels the language of the Federal Employers Liability Act [FELA]. ${ }^{21}$ Since there have been no decisions under the ICA defining more precisely the effect of its jurisdictional section upon the state courts, ${ }^{22}$ it is helpful to examine the Supreme Court's interpretation of the similar language of the FELA.

In Mondou v. New York, N.H. E H.R.R., ${ }^{28}$ the Supreme Court of Errors of Connecticut had affirmed the dismissal of a complaint under the FELA on the ground that state courts need not enforce a federal statute. $^{24}$ In reversing, the Supreme Court of the United States said that to the extent that a particular state trial court has inherent jurisdictional capacity adequate to entertain a suit of the type brought under the FELA, it must take jurisdiction of the federally created action, even if the suit is brought by a non-resident plaintiff against a non-resident defendant for a cause of action arising outside the forum state. ${ }^{25}$

Later decisions have mitigated the sweeping Mondou rule and indeed have become more important than the original decision. One of the most important of these modifications was made in Douglas $v$. New

20 "The district courts of the United States and the United States courts of any Territory or other place subject to the jurisdiction of the United States shall have jurisdiction of violations of this title or the rules, regulations, or orders thereunder, and, concurrently with State and Territorial courts, of all suits in equity and actions at law brought to enforce any liability or duty created by, or to enjoin any violation of, this title or the rules, regulations, or orders thereuuder." 54 Stat. 844 (1940), I5 U.S.C. $\S 80 a-43$ (1958). Four of the other five federal securities acts have subotantially the same wording. The Securities Act of 1933,48 Stat. 86, 15 U.S.C. \& $77(v)$; the Trust Indenture Act of 1939,53 Stat. 1375,15 U.S.C. $\$ 77$ (vvv) (1958); the Public Utility Holding Company Act of 1935,49 Stat. 835,15 U.S.C. $\$ 79(\mathrm{y})(1958)$; the Investment Advisers Act of 1940, 54 Stat. 856, 15 U.S.C. $880 b-14$ (1958).

"1 "The jurisdiction of the courts of the United States under this chapter shall be concurrent with that of the courts of the several States." 35 Stat. 66 (1910), as amended 45 U.S.C. 856 (1958). The question has also arisen in other contexts. See, e.g., Testa v. Katt, 330 U.S. 386 (1947); 2 Loss 978 n.46r.

32 This statement is made on the basis of a reading of every case cited by the fifty state Shepard's Citators as having cited the ICA through the advance sheets of late 3961 . See note 3 supra.

223 U.S. I (1912).

${ }^{26}$ Mondou v. New York, N.H. \& H.R.R., 82 Conn. 373, 73 Atl. 762 (1909).

${ }^{2 x} 223$ U.S. at 59. Referring to the two court systems, state and federal, the Court remarked: "The two together form one system of jurisprudence, which constitutes the law of the land for the State...."Id. at 58 . 
York, N.H. E'H.R.R. ${ }^{26}$ There the Supreme Court was confronted with a New York statute providing that " $[\mathrm{A}] \mathrm{n}$ action against a foreign corporation may be maintained by a non-resident only when the foreign corporation is doing business within the state."27 New York had always permitted residents of the state to bring suit against foreign corporations for foreign torts, but where the plaintiff was a non-resident, the trial courts had construed the statute as granting them discretion to allow or refuse the action, ${ }^{28}$ even if that action were one to enforce a federally created right. This distinction between residents and nonresidents was predicated on the "may" in the statute and applied even when the non-resident was in fact a citizen of New York. The Supreme Court, speaking through Mr. Justice Holmes, upheld this discretionary exclusion of non-resident plaintiffs as a valid ground on which to give the state taxpayers, who supported the state court system, a preference in overcrowded tribunals. ${ }^{29}$

The basic philosophy of the Douglas case was that states could regulate the use of their own court systems in a reasonable manner, even where a federal right was being asserted. In keeping with the doctrine of reasonable regulation, it has been settled that plaintiffs with federal rights in state courts may be barred by reasonable state juris-

\footnotetext{
20279 U.S. 377 (1929).

${ }^{27}$ At that time, N.Y. Cons. Laws ch. 24, § 47 (Cahill 1923). (Emphasis added.)

${ }^{28}$ This practice was approved in Murnan v. Wabash Ry., 246 N.Y. 244, 158 N.E. $508(1927)$.

${ }^{30}$ Holmes said that the statute did not require state enforcement but only empowered it. 279 U.S. at 387 . (Emphasis added.) He went on to qualify this apparent reversal of the philosophy of the Mondou case by stating that there is no state duty of enforcement "as against an otherwise valid excuse." 279 U.S. at 388 . Set in the context of the whole opinion, the latter phrase is more representative of the holding of the case.

The Douglas modification of the Mondou rule was apparently impelled by a forum shopping problem. The Minnesota courts, for example, were overrun with suits between non-residents. This is reflected in the concurring opinion of Justice Stone in Winders v. Illinois Cent. R.R., 177 Minn. 1, 5, 223 N.W. 291, 293 (1929), where lie complains of the expense to which Minnesota taxpayers are put to support a battleground for these actions. The Winders case came down in January of 1929, about three months before the reargument in the Douglas case. Although Winders is not cited, that the same policy reason influenced Holmes is indicated by this phrare: "[I]t is they [the taxpaying residents] who pay for maintaining the Courts concerned." 279 U.S. at 387 . Nearly a year after Doughas, in Boright v. Chicago, R.I. \& P.R.R., 180 Minn. 52, 230 N.W. 457 (1930), Justice Stone, again in dissent, urged the Minnesota Supreme Court to take advantage of the greater freedom of the Douglas opinion. The majority, however, considered itself bound by its own pre-Douglas decisions and refused to adopt a more liberal rule.
} 
dictional and venue statutes, ${ }^{30}$ and the equitable doctrines of laches and estoppel..$^{31}$ The same rule presumably would apply to statutes of limitation. ${ }^{32}$

Applying the Mondou-Douglas rule to the ICA, state courts must enforce rights and duties arising under the act, subject only to the power of the state to set up restrictions in the interest of maintaining a forum reasonably accessible to the taxpayers who support it. Thus, for some purposes the legislature of a state sits in Washington. ${ }^{33}$

\section{The Several Types of Private Actions}

Having established the duty of state courts to enforce rights and duties arising under the ICA, it remains to define the actions which come within this classification. Briefly stated, there are three bases of private rights of action associated with the ICA: express rights of action, judicially created rights of action, and "hybrid" rights of action.

Express rights of action, of little importance in the ICA, are founded on statutory language providing a private plaintiff with a specific remedy for a specific wrong..$^{34}$ These rights clearly arise under the ICA and, as such, must be enforced pursuant to the Mondou-Douglas rules. ${ }^{35}$

\footnotetext{
${ }^{30}$ Herb v. Pitcairn, 324 U.S. 117,123 (1945); Douglas v. N.Y., N.H. \& H.R.R., 279 U.S. 377 (1929).

"Wood v. Chesborough, 228 U.S. 672 (1913). "[W] here the non-federal ground has fair support, we are not at liberty to inquire whether it is right or wrong, but must accept it, as we do other state decisions of non-federal questions." Enterprise Irrigation Dist. v. Farmers Mut. Canal Co., 243 U.S. 157, 164 (1917).

But forum non conveniens was held in Schultz v. Union Pac. R.R., 257 P.2d 1003, I 8 Cal. App. 2d 169 (1953), to be an insufficient ground for rejection of an FELA action. Accord, Price v. Atchison, T. \& S.F. Ry., 259 P.2d 664, (Cal. App. 1953). Contra, Mooney v. Denver \& R.G.W.R.R., I 18 Utah 307, 221 P.2d 628 (1950).

Walton v. Pryor, 276 Ill. 563, II5 N.E. 2 (1916), holds that a state statute which bars actions under the FELA and similar state action for out-of-state injuries was constitutional because it applied equally to residents and non-residents, federal and state actions.

"Some express liability sections of the securities acts are internally provided with a time limitation, but there is no statute of limitations for rights arising under the securities acts generally. A bill to provide such a statute, H.R. 2788, was favorably reported out of the House Judiciary Committee but not passed. H.R. Rep. No. II4I, 79th Cong. Ist Sess. (1945). 3 Loss 177 I n.297.

"Cf. 2 Loss 987.

"See 54 Stat, 837 (1940), 15 U.S.C. $\$ 802-29$ (f) (1958). This section incorporates by reference the well known short swing profits liability of $\S 16(\mathrm{~b})$ of the Securities Exchange Act of 1934, 48 Stat. 896, 15 U.S.C. $\S 78(\mathrm{p})$ (1958), and is the only express right of action under the ICA.

${ }^{38}$ The parallelism here with the FELA is nearly perfect. In both instances the rights of action are expressly created by a federal statute concurrently enforceable in state and federal courts.
} 
Judicially created rights of action are those rights of action which are not a product of the statutory language itself but which come about through the application of some doctrine external to the statute. Principally they have arisen when the courts have applied the tort "violation of statute" doctrine ${ }^{38}$ to provisions in the ICA which merely declare certain acts unlawful or provide administrative sanctions without expressly allowing private remedies. Whether rights of action created by the tort doctrine arise under the ICA, and hence are federal law, or whether they are a product of state law is a question of some complexity. Generally, when the lower federal courts apply the tort doctrine to the ICA, they are applying federal common law and the right of action produced is federal in character. ${ }^{88}$ When the state courts apply the tort doctrine to the ICA, then arguably, the state or federal character of the resulting right turns upon the source of the doctrine $^{38}$ and the mechanics of its application. ${ }^{40}$ It is necessary here

"This doctrine is examined in some detail in the next eection. For present purposes it is only necessary to point out that it has been used by some courts to mechanically produce private actions under the ICA and other securitics acts.

${ }_{27}$ Deitrick v. Greaney, 309 U.S. 190 (1940); D'Oench, Duhme \& Co. v. FDIC, 315 U.S. 447 (1942); Mater v. Holley, 200 F.2d 123 (5th Cir. 1952); United States v. Silliman, 167 F.2d 607, 6ro-II (3d Cir.), cert. denied, 335 U.S. 825 (1948); 2 Loss 994 R.5 9 ; 59 HARV. L. REV. 970-72 (1946).

"There are two methods of analysis here, but under either the same concluaion obtains. (I) The tort doctrine is completely external to the statute itself; when applied it creates rights of action by operation of law, just as a fee tail is converted into a fee simple by statutes in most American states. Under this analysis, the character of the right of action is ultimately determined by the source of the tort doctrine which creates it. Since federal common law is being used, the right produced is federal in character.

(2) Regardless of the method used by the courts in allowing rights of action under a federal statute, those rights reflect an attempt to give full force and effect to provisions of the statute. Furthermore, in the absence of the statute there would be no comparable standard to enforce. Therefore the private right of action arises under the federal statute and is federal law.

${ }^{30}$ If the state courts profess to apply federal tort law then the right of action will be federal in character under analysis (1) or (2) in note 39 supra. If the state courts apply state tort law, then the character of the action turns upon the considerations developed in note $4 \mathrm{I}$ infra.

${ }^{40}$ As was seen in note 39 supra, the choice of theory used in the lower federal courts has no effect on the character of the action. Under either theory, the resulting private right is federally created.

However, where the private right of action is asserted in a state court, and where the court uses state tort doctrines, see note 40 supra, then the choice of analysis becomes critical. Under the first analysis of note 39 supra, the character of the action turns on the source of the tort doctrine used. Since the state court plaintiff's theory centers on the state tort doctrine, the right of action is state law. The second analysis in note 39 
only to point out that an unsolved and very conceptualistic problem exists, the resolution of which is the key to the applicability of the Mordou-Douglas rule."1

Hybrid rights of action arise under Section 47 (b) of the ICA. 12 This section expressly renders certain contracts void with respect to the rights of persons violating the act. For purposes of actions brought by an innocent party to avoid such a contract and to seek restoration of the status quo, ${ }^{48}$ it would seem that a right arising under the ICA is asserted, whether the action is brought in a federal or state court." However, some federal courts have allowed tort damages under section

supra, would reason that the cause of action should not turn on doctrinaire metaphysics but rather on more pragmatic considerations. Since these rights arise under a federal statute they should be considered federal law regardles of the court in which they are being enforced. Further, such a holding would tend to produce more uniformity of enforcement through the Supreme Court's power of review.

Professor Loss points out that in any event the state courts could grant causes of action based on violation of state common law standards analagous to the ICA. These would clearly be state rights, unreviewable by the Supreme Court. 2 Loss 999.

"2 The question has not been spoken to at present by the Supreme Court. At the time of this writing the Court has accepted certiorari in Brouk v. Managed Funds, 286 F.2d 901 (8th Cir.), cert. granted, 366 U.S. 958, Motion of Solicitor General for leave to participate in oral argument granted, 368 U.S. 873 (1961). This action, however, was brought in a federal district court and thus does not raise the question of ICA enforcement in a state court.

${ }_{54} 5$ Stat. 846 (1940), 15 U.S.C. \& 80a-46(b) (1958). "Every contract made in violation of any provision of this title [i.e., the ICA] or of any rule, regulation, or order thereunder, and every contract heretofore or hereafter made, the performance of which involves the violation of, or the continuance of any relationship or practice in violation of, any provision of this title, or any rule, regulation, or order thereunder, shall be void (I) as regards the rights of any person who, in violation of any such provision, rule, regulation, or order, shall bave made or engaged in the performance of any such contract, and (2) as regards the rights of any person who, not being a party to such contract, shall have acquired any right thereunder with actual knowledge of the facts by reason of which the making or performance of such contract was in violation of any such provision, rule, regulation, or order."

48 These remedies follow by operation of law whenever a contract is declared void with respect to the rights of one of the parties to it. 6 CorBIN, ConTracts $\$ 1540$ (1951); RESTATEMENT, CoNTRACTS $\S 601$ (1932). This has long been an established principle under Blue Sky Laws. Kneeland v, Emerton, 280 Mass. 371,183 N.E. 155, 87 A.L.R. I (1932). In that context, it has been said that the rule applied whether the statute declared the contract voidable, void, or unlawful.

"It is plausible to reason in the fashion of the first analysis of note 39 supra, and conclude that the source of the contract law utilized to allow an action for restitution should determine the character of the action. However, this is an unduly hairsplitting approach and reveals the sometime weakness of strict logic in determining legal results. It is submitted that the actions for restitution and the right to avoid such a contract are such an integral part of the phraseology of $\S 47$ (b) that they should be held to have the status of federal law. 
47 (b) ${ }_{3}^{45}$ presumably based upon common law principles. In the lower federal courts, as in the case of the tort doctrine, these hybrid remedies are federal in character in that they are produced by federal common faw. ${ }^{48}$ However, in the state courts, the same conceptualistic problems are encountered as exist under the tort doctrine. ${ }^{47}$

$\therefore$ Upon the determination of the federal-state character of these hybrid and private rights of action turns the applicability of the Mondour Douglas rules and the jurisdiction of the Supreme Court to review state court decisions. ${ }^{48}$ Ultimately the Supreme Court must decide the issue; until its resolution the state courts are bound only to enforce the rights of the ICA which are express in character. A determination by the Supreme Court that private rights of action are to be granted under the act ${ }^{49}$ would give them the status of express rights of action, and render them enforceable in the state courts to the extent required by the Mondou-Douglas rule.

\section{An Analysis of the Tort "Violation of Statute" Doctrine}

Express and "hybrid" rights of action under the ICA find their basis in the language of the act itself. Judicially created rights of action, on the other hand, rest in most cases on the application of the

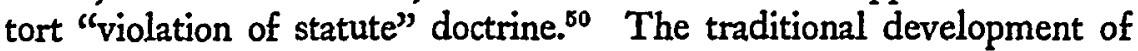
the tort doctrine has been in terms of negligence, as is illustrated by two frequently cited articles by Professors Lowndes and Thayer. ${ }^{51}$

${ }^{45}$ Kardon v. Natl. Gypsum Co., 69 F. Supp. 512 (E.D. Penn. 1946) 3 Geismar v. Bond \& Goodwin, 40 F. Supp. 876 (S.D.N.Y. 194I). The reasoning in these cases is grossly lacking. Judge Coxe in the Geismar case correctly concludes that a right of action exists under $\S_{47}$ (b) but then goes on to say that damages also may be awarded. The first proposition is good contract law, note 44 supra, but the second, disposed of in one sentence and an incorrect case citation [Deckert v. Independence Corp., 31 I U.S. 282 (1940), cited at 878], is rather novel if taken at all literally. The court in the Kardon case passed the question with a citation to Geismar, treating it as "well settled."

"Cf. note 39 supra.

ir These problems seem to be more genuine here than under the tort doctrine, for it is certainly arguable that in approving $\$ 47$ (b), Congress intended to take advantage of precedents of state contract law and especially the large number of decisions under the Blue Sky Laws which have interpreted similar provisions. Compare note 45 supra.

"Hart, The Relations between States and Federal Law, 54 ColuM. L. REv. 489, 537 (1954).

10 This question may be answered by the Supreme Court in Brouk v. Managed Funds, Inc., 286 F.2d gor (9th Cir.), cert. granted, 366 U.S. 958, Motion of Solicitor General for leave to participate in oral argument granted, 368 U.S. 873 ( $196 \mathrm{I}$ ).

${ }^{\circ}$ See generally Restatement, TORTs $\$ 286$ (1934); 2 Harper \& James, Torts $\S 17.6$ (1956); Prosser, Torts $\$ 34$ (2d ed. 1955).

"1 Lowndes, Cioil Liability Created by Criminal Legishation, 16 MINN. L. REv. 361 
Professor Thayer sees the violation of a protective statute as negligence per se, i.e., negligence as a matter of law. ${ }^{52}$ The better view, however, as propounded by Professor Lowndes, is that violation of a statutory standard is but some evidence of negligence, to be considered by the fact-finder along with other evidence. ${ }^{53}$. Under either. view, the private right of action rests upon negligence, and is subject to all the safeguards and defenses inherent in this method of apportioning the burden of social misconduct.

The federal securities cases, however, have not talked in terms of negligence. They have seen the doctrine as a black-letter rule which operates upon those statutes enacted for the protection of a special group and mechanically generates private rights of action in members of the group. In Baird v. Franklin, ${ }^{54}$ the court said:

The fact that the statute provides no machinery or procedure by which the individual right of action can proceed is immaterial. ${ }^{.5}$ It is well established that members of a class for whose protection a statutory duty ${ }^{66}$ is created may sue for injuries resulting from its breach and that the common law will supply a remedy if the statute gives none. ${ }^{\mathrm{sT}}$

In Kardon v. National Gypsum Co., ${ }^{58}$ the court, relying on Section 286 of the Restatement of Torts, concluded: "The disregard of the command of a statute is a wrongful act and a tort." ${ }^{35}$ In Fischman v. Raytheon $M f g . C_{0}{ }^{60}$ the court said:

(1932); Thayer, Public Wrong and Private Action, 27 HARv. L. REv. 317 (1914).

"Thayer first explodes the "duty theory" reasoning used by some courts in these concise words, which could well be taken to heart in many modern federal securities cases: "Too often the mere statement of a conclusion that 'the statute creates a duty to the plaintiff' is used as if it furnished some reasons in its own support. At times it is coupled with the further assertion that 'the plaintiff therefore has a remedy,' as if this were something more than an identical proposition." Thayer, supra note 52, at 318-19. For an equally incisive exposé of this type of reasoning, done in a humorous fashion, see the tale of the totem animal killer in Ross, Tu-Tu, 7o HARV. L. REv. 812 (1957).

Thayer then goes on to reach the conclusion mentioned in the text above: "Whenever due care is the issue, the breach of the statute supplies the legal equivalent of negligence. The defendant is in no position to meet the test of the prudent man." Thayer, supra note 52, at 334. But see 2 HARPER \& JAMES, TORTs 995 (1956).

${ }^{82}$ Lowndes, supra note 52 , at 376 .

s4 14 I F.2d 238 (2d Cir. 1944).

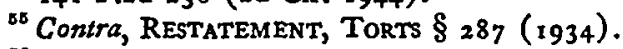

so But see Thayer's reasoning on the use of the "duty" theory at note 53 supra.

"7 Baird v. Franklin, 141 F.2d 238, 245 (2d Cir. 1944).

68 F. Supp. 512 (E.D. Pa. 1946).

"Id. at 513 .

${ }^{60}$ r8 F.2d 783,787 (2d Cir. 1951 ). 
[The Securities Act] does not explicitly authorize a civil remedy. Since, however, it does make "unlawful" the conduct it describes, it creates such 2 remedy.

Nothing the courts say in these decisions indicates that they are at all cognizant of the contrast between the facts presented in the Baird, Kardon, and Fischmass cases and the factual situations envisioned by Lowndes, Thayer, and subsequent commentators. The Baird case involved willful and continuous violations of Section $6(\mathrm{~b})$ of the Securities Exchange Act by the New York Stock Exchange. ${ }^{01}$ The Kardon case concerned a fraudulent conspiracy aimed at inducing the plaintiff to part with stock at less than its true value. The Fischman case involved losses arising out of fraudulent conduct in the use of a prospectus.

In contrast, the traditional tort doctrine is concerned with the attributes of the reasonable man, the effect that his violation of statute will have on the negligence question, and the division of function between judge and jury. ${ }^{62}$ It can hardly be said that the stock "churning," the excessive fees, "04 the paying of "kick backs," and the other abuses"s which have occurred despite the ICA are products of negligence, of an unfortunate accident. ${ }^{B 6}$

is 48 Stat. 885 (1934), 15 U.S.C. $§ 78(f)$ (b) (1958).

"Professor Lattin says there is no right to a jury in a shareholders' derivative suit for it is an action in equity. LATTIN, Corporntions 350 (8959). Therefore, no question of judge and jury function could arise. Some states will allow a jury in an equity action for special findings of fact. In Delaware, for example, the Court of Chancery may order a trial of such issues at the bar of the Superior Court. DEL. CoDE ANN. tit. 10, $\S 369$ (1953). But such an order is in the discretion of the court. Saunders v. Saunders, 3 I Del. Ch. 514, 7 I A.2d 258 (1950).

${ }^{33}$ See note 16 supra.

os Excessive fee structures seem to be the prime point of attack on investment coinpanies by stockholders today. It is often alleged that the management contracts do not reflect the lower relative cost incurred in the operation of a large fund as compared to smaller funds. See testinnony of William J. Thorold in SEC, REPORT OF INVESTMENT Trusts and Investment Companies pt. III, at 2491 (1941). See Comment, 196: DUKE L.J. 421 n.2. Excessive fee structure was an allegation in Saminsky v. Abbott, CCH Fed. SEC. L. Rep. I 91,047 (Del. Ch. Sept. 18 , 196I).

${ }^{65}$ SEC, REPoRt ON INVESTMENT TRUSTS AND INVESTMENT COMPANIES, pt. III, at 1563-1934, 1566-69, 1874-1934 (1940). See also Lutz v. Boas, 171 A.2d 381 (Del. Ch. 1961) (kickbacks); 3 Loss $1421-1528$ (2d ed. 1961) (fraudulent promotional schemes).

${ }^{\circ 0}$ This is not to say that there is a complete absence of precedent for the application of the tort "violation of statute" doctrine to intentional violations of statute. In Texas \& Pac. Ry. v. Rigsby, 24I U.S. 33, 39-40 (1915), the Supreme Court, construing the Safety Appliance Act, 27 Stat. 53 I (1893), as amended, 45 U.S.C. §§ I-7 (1958), said that where the command of a statute is disregarded, there is an implied right of action. But the argument, as it is expounded by many of the recent securities cases, that 
In reality the tort doctrine is merely a slightly more sophisticated way of expressing the old half-truth that "for every wrong there is a remedy." Lowndes concluded that courts in fact have unlimited power to legislate, but are somewhat self-conscious about exercising such power. ${ }^{.8}$ The federal courts have found it far easier to pronounce the availability of a civil remedy for a plaintiff by relying on the Restatement of Torts, Prosser, Lowndes, and Thryer, than to appear to be speaking ex cathedra. Thus, in spite of the illegitimate parentage and doubtful relevance of the tort doctrine, these courts often have been willing to forego close analysis in reliance on its authority. ${ }^{69}$ The doctrine really functions as a crutch, an impressive backdrop against which a bit of judicial sleight of hand may be indulged in without fear of its identification. However, pending recognition of private rights of action by the Supreme Court, state courts are free to render their own considered judgment as to the advisability of allowing these actions.

\section{Conclusion}

By the Mondou-Douglas rule, the Supreme Court has declared that state court enforcement of concurrently enforcible federal statutes is a matter of right, and may not be barred save in the interests of reasonable judicial administration.

The extent of the application of the Mondou-Douglas rule, however, turns on the federal or state character of the specific private right of action in question. Although choice of theory here is crucial, the

this decision stands for a doctrine which will, automatically and regardless of negligence, convert any statute enacted for the protection of a special group into a vehicle of civil liability for the private plaintiff is presumptive in at least two respects. First, the Court emphasized the implementation of congressional purpose instead of the application of a black letter rule. Second, the Rigsby case probably was a negligence action even though the court found the policy of protection so strong that it deemed it unnecessary to pass on the question. The Court said that $\S 8$ of the act (27 Stat. $53 \mathrm{I}, 45$ U.S.C. $\$$ 7 (1958) in actions brought in reliance on the act, assumption of risk would be no bar) renders "irresistible" the inference of a private right of action. Id. at 4o. This reasoning is sound, for why would Congress modify the substantive rights of a personal injury plaintiff as it did in $\S 8$, if it did not anticipate the bringing of a personal injury action?

o7 "A pious cant which adds little to clear thinking ... is the trite jingle that the law will suffer no wrong without a remedy. If this means that the law will suffer no moral wrong without giving a remedy, it is obviously untrue. If it means that the law will suffer no legal wrong without a remedy this is mere tautology, since the existence of a legal wrong presupposes a legal remedy." Lowndes, supra note 52, at 364-65.

${ }^{\text {os }}$ Id. at 363 .

${ }^{\circ 0}$ See note 46 supra. 
method by which the federal or state character of the action is determined has not been made definite; in some cases equally logical arguments may be made for either result. The real issue seems to be whether the advantage of uniform enforcement of the ICA through the Supreme Court's power of review outweighs the Court's reluctance to be a final arbiter of details of the application of substantive law in state forums.

The basic question, of course, is whether private rights of action under the ICA should be recognized at all. The lower federal courts have not been closely analytical when granting these rights. In essence they exist because the courts thought they should exist, even though Congress did not expressly so provide. It is submitted that state courts, when considering the granting of private rights of action under the ICA, should more carefully consider the rationale and the implications of such judicial legislation than did their federal predecessors. If, indeed, the existence of private rights of action turns on the propriety of the application of the tort doctrine, then they should not be granted. 